Article

\title{
MMP-2/9-Specific Activatable Lifetime Imaging Agent
}

\author{
Marcus T.M. Rood ${ }^{1}$, Marcel Raspe ${ }^{2}$, Jan Bart ten Hove 1,3, Kees Jalink ${ }^{2}$, Aldrik H. Velders ${ }^{1,3}$ \\ and Fijs W.B. van Leeuwen ${ }^{1,3, *}$
}

1 Interventional Molecular Imaging Laboratory, Department of Radiology, Leiden University Medical Center, Leiden 2300RC, The Netherlands; E-Mails:m.t.m.rood@lumc.nl (M.T.M.R.); janbart.tenhove@wur.nl (J.B.H.); aldrik.velders@wur.nl (A.H.V.)

2 Division of Cell Biology I, Netherlands Cancer Institute, Amsterdam 1066CX, The Netherlands; E-Mails: m.raspe@nki.nl (M.R.); k.jalink@nki.nl (K.J.)

3 Laboratory of BioNanoTechnology, Wageningen University, Wageningen 6700EK, The Netherlands

* Author to whom correspondence should be addressed; E-Mail: f.w.b.van_leeuwen@lumc.nl; Tel.: +31-71-526-6029.

Academic Editor: Niko Hildebrandt

Received: 2 April 2015 / Accepted: 6 May 2015 / Published: 12 May 2015

\begin{abstract}
Optical (molecular) imaging can benefit from a combination of the high signal-to-background ratio of activatable fluorescence imaging with the high specificity of luminescence lifetime imaging. To allow for this combination, both imaging techniques were integrated in a single imaging agent, a so-called activatable lifetime imaging agent. Important in the design of this imaging agent is the use of two luminophores that are tethered by a specific peptide with a hairpin-motive that ensured close proximity of the two while also having a specific amino acid sequence available for enzymatic cleavage by tumor-related MMP-2/9. Ir(ppy) 3 and Cy5 were used because in close proximity the emission intensities of both luminophores were quenched and the influence of Cy5 shortens the $\operatorname{Ir}(\mathrm{ppy})_{3}$ luminescence lifetime from $98 \mathrm{~ns}$ to $30 \mathrm{~ns}$. Upon cleavage in vitro, both effects are undone, yielding an increase in $\operatorname{Ir}(\mathrm{ppy})_{3}$ and Cy5 luminescence and a restoration of $\operatorname{Ir}(\mathrm{ppy})_{3}$ luminescence lifetime to $94 \mathrm{~ns}$. As a reference for the luminescence activation, a similar imaging agent with the more common Cy3-Cy5 fluorophore pair was used. Our findings underline that the combination of enzymatic signal activation with lifetime imaging is possible and that it provides a promising method in the design of future disease specific imaging agents.
\end{abstract}


Keywords: iridium; lifetime imaging; luminescence; enzymatic activation; MMP; FRET; fluorescence

\section{Introduction}

The use of luminescence in molecular imaging has many advantages. Luminescence is a high-resolution, real-time imaging technology that requires low concentrations of label. However, there are also disadvantages. Two main disadvantages of luminescence imaging are the presence of autofluorescence and background signal as a result from non-specific retention of an imaging agent [1].

Autofluorescence is the combined name for all emissions by endogenous compounds, and is mainly associated with molecules such as NADH and flavins [2]. Although the emission intensity of such endogenous molecules is generally weaker than that of specifically designed luminophores, these emissions can still obscure imaging findings [3]. Luminescence lifetime, a parameter that describes the time between excitation and signal emission, offers a technology that can be exploited to separate luminescent signals of different origins. Most endogenous and organic luminophores have luminescence lifetimes in the same range $(0.1-10 \mathrm{~ns})$ [4]. To reduce the background caused by endogenous emissions, dedicated lifetime imaging agents should have a lifetime that lies well beyond this range [5]. A luminescence lifetime of $20 \mathrm{~ns}$ can already easily be separated from shorter lifetimes using lifetime gating [6]. There is also a downside to lifetime elongation, since the use of longer luminescence lifetimes decreases imaging speed and photon flux. This is important if small volumes and low concentrations are measured, for instance in confocal microscopy, and also when real-time images are required, like in image-guided surgery. To obtain high-quality imaging that is fast enough for these applications, a maximum lifetime of $100 \mathrm{~ns}$ has been estimated [7]. Such luminescence lifetimes cannot be obtained using organic luminophores but are typical for transition metal ion complexes based on, e.g., ruthenium (II) or iridium (III) [8-10].

The presence of non-specifically bound imaging agent increases background signal and thereby reduces imaging quality. Imaging agents can for instance remain present in blood, or give non-specific uptake in tissue/organs [11]. In luminescence-based molecular imaging, this disadvantage can be overcome by disease-related enzyme-controlled activation of a luminescent signal; before activation, the signal should be in the off-state (quenched) [12]. The most promising enzymes in this application are the ones that are associated with the presence of malignant tissue, such as cathepsins [13], gamma-glutamyl transpeptidase [14] and matrix metalloproteinases (MMP) [15,16]. Many different photophysical and chemical quenching mechanisms have been studied for activatable luminescent imaging agents, including Förster Resonance Energy Tranfer (FRET) [17-19], photon-induced electron transfer [20,21], chemical reactions on the luminophore itself [22], and spin-orbit coupling [23]. In theory, for each enzyme that can cleave a chemical bond, a suitable activatable imaging agent can be generated to ensure local and specific signal enhancement [24].

MMP-2 and MMP-9 are closely related and they both cleave the same PLGLA peptide sequence $[15,25]$. MMP-2/9 have the natural function of cleaving the extracellular matrix, which is rarely required in healthy tissue, but since tissue reconstruction is needed around fast-growing tumors, 
the presence of MMP-2/9 is said to be related to the presence of invasive tumor tissue [26,27]. The family of MMPs has proven its potential in oncology related molecular imaging, with applications extending as far as fluorescence-guided surgery [28].

We have previously shown that covalent attachment of $\operatorname{Ir}(\mathrm{ppy})_{3}$ and Cy5 using a disulfide bond generates a luminophore pair in which a combination of spin-orbit coupling by the iridium atom and FRET quenches the luminescent signal of both luminophores [29]. This quenching was accompanied by a shortening of the $\operatorname{Ir}($ ppy) 3 related lifetime. Cleavage of the connective disulfide bond led to the restoration of the luminescence intensity of both luminophores and an elongation of the lifetime of the $\operatorname{Ir}(\text { ppy })_{3}$ emission [29]. In this approach, the luminescence lifetime should allow for the separation of luminescence signal from autofluorescence, while the signal activation should reduce the background signal generated by non-specifically distributed imaging agent [29-31]. We therefore reasoned that a $\operatorname{Ir}(\text { ppy })_{3}-\mathrm{Cy} 5$ pair combined with MMP-2/9 selective signal activation has the potential to provide a new generation of molecular imaging agents.

\section{Experimental Section}

\subsection{General}

All chemicals were obtained from commercial sources and used without further purification. HPLC was performed on a Waters system by using a 1525EF pump and a 2489 UV detector. For preparative HPLC a Dr. Maisch, GmbH, Reprosil-Pur 120 C18-AQ $10 \mu \mathrm{m}(250 \times 20 \mathrm{~mm})$ column was used and a gradient of $0.1 \%$ TFA in $\mathrm{H}_{2} \mathrm{O} / \mathrm{CH}_{3} \mathrm{CN}$ (95:5) to $0.1 \%$ TFA in $\mathrm{H}_{2} \mathrm{O} / \mathrm{CH}_{3} \mathrm{CN}$ (5:95) in 40 min was employed. For analytical HPLC a Dr. Maisch, GmbH, Reprosil-Pur C18-AQ $5 \mu \mathrm{m}(250 \times 4.6 \mathrm{~mm})$ column was used and a gradient of $0.1 \%$ TFA in $\mathrm{H}_{2} \mathrm{O} / \mathrm{CH}_{3} \mathrm{CN}(95: 5)$ to $0.1 \%$ TFA in $\mathrm{H}_{2} \mathrm{O} / \mathrm{CH}_{3} \mathrm{CN}$ $(5: 95)$ in $40 \mathrm{~min}$ was employed. HPLC traces of the final compounds are included in the Supplementary Materials, conforming $>95 \%$ purity. MALDI-ToF measurements were performed on a Bruker Microflex system.

\subsection{Synthesis of Peptide-Cy5 (1)}

Two very similar peptides were synthesized on Rink Amide Resin using standard Fmoc-strategy solid phase peptide synthesis methods. The sequences were as follows:

$$
\begin{aligned}
& \mathrm{NH}_{2} \text {-eeee GPLGLArrrrrrrrk-RESIN (L-amino acids) } \\
& \mathrm{NH}_{2} \text {-eeeeegplglarrrrrrrrk-RESIN (D-amino acids) }
\end{aligned}
$$

The only difference between the two peptides was the stereochemistry of the six amino acids of the cleavage site (highlighted in red in Scheme 1). Both peptides were treated equally for the next steps. $\mathrm{Cy} 5-\mathrm{COOH}$ was coupled to the peptide using standard protocol for solid phase labeling. In short, to the resin-bound peptide with all protecting groups attached $(10 \mu \mathrm{mol})$ in DMF $(2 \mathrm{~mL})$ was added Cy5 $(17 \mathrm{mg}$, $20 \mu \mathrm{mol})$, PyBOP $(10.4 \mathrm{mg}, 20 \mu \mathrm{mol})$ and DIPEA $(6.8 \mu \mathrm{L}, 40 \mu \mathrm{mol})$. The reaction was stirred overnight at RT, after which the resin was washed three times with DMF and three times with DCM. After drying, the dark-blue resin in vacuum, the peptide was cleaved from the resin using $1 \mathrm{~mL}$ cleavage mixture (92.5\% TFA: $5 \% \mathrm{H}_{2} \mathrm{O}: 2.5 \%$ TIS) for $4 \mathrm{~h}$ at RT. The solution was collected and the 
resin was washed with TFA until the solution became colorless. The TFA solution was added dropwise to MTBE:hexane $1: 1$ at $-20{ }^{\circ} \mathrm{C}$ to give a blue precipitation. The blue precipitation was washed with MTBE:hexane 1:1, dissolved in $\mathrm{H}_{2} \mathrm{O}$ and lyophilized to give a blue solid.

For $\mathbf{1 L}$, the yield was $27.4 \mathrm{mg}(87 \%) . \mathrm{m} / \mathrm{z}(\mathrm{MALDI}-\mathrm{ToF}):\left[\mathrm{C}_{138} \mathrm{H}_{231} \mathrm{~N}_{48} \mathrm{O}_{40} \mathrm{~S}_{3}\right]^{+}$calcd 3298.9 , found 3298.4. For 1D, the yield was $12.0 \mathrm{mg}(36 \%) . \mathrm{m} / \mathrm{z}$ (MALDI-ToF): $\left[\mathrm{C}_{138} \mathrm{H}_{231} \mathrm{~N}_{48} \mathrm{O}_{40} \mathrm{~S}_{3}\right]^{+}$ calcd 3298.9, found 3298.9.

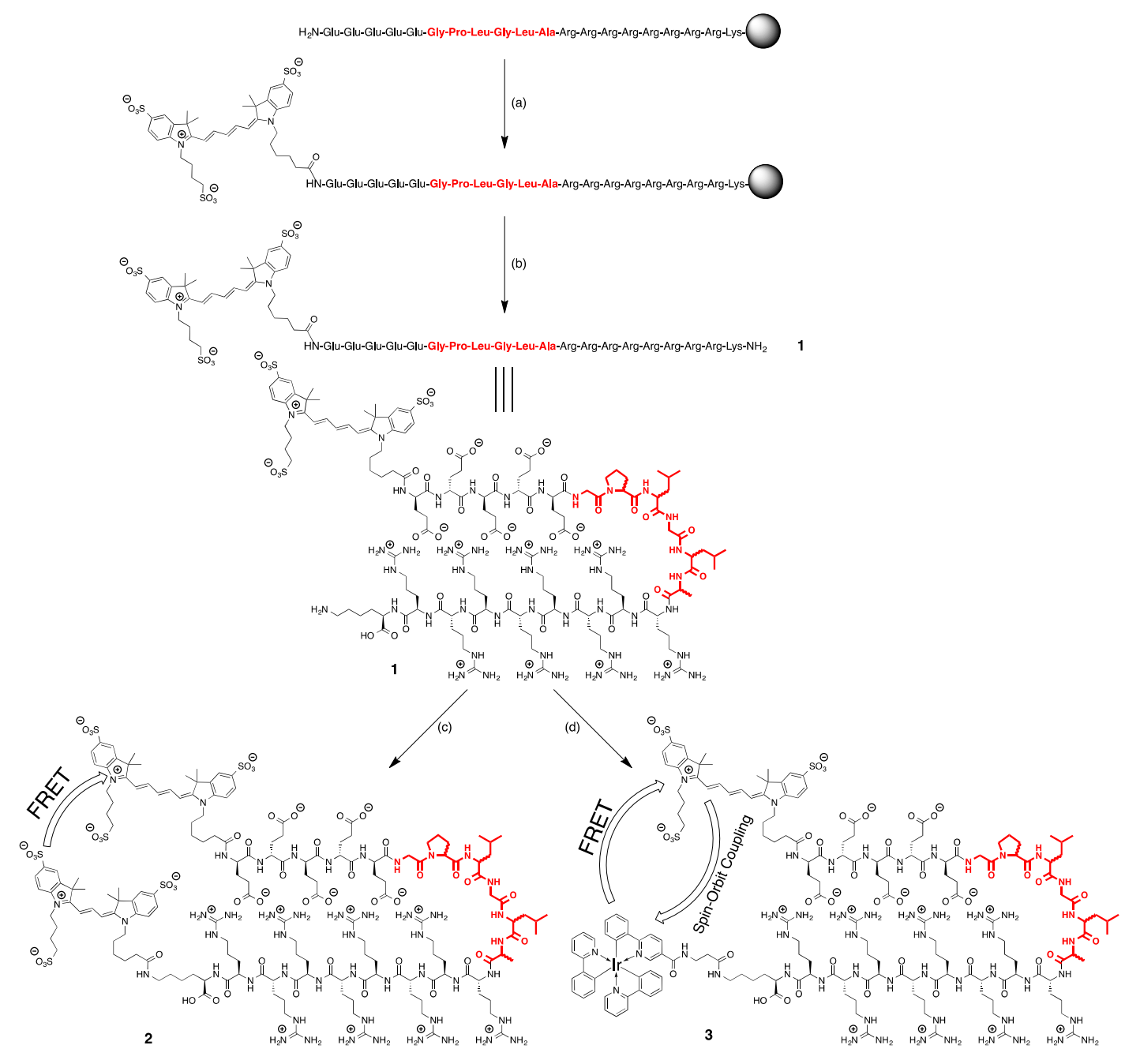

Scheme 1. Synthesis of the activatable imaging agents discussed in this research. (a) Cy5, PyBOP, DIPEA, DMF; (b) TFA, $\mathrm{H}_{2} \mathrm{O}$, TIS; (c) Cy3-NHS, $\mathrm{H}_{2} \mathrm{O} / \mathrm{DMSO}$; (d) $\operatorname{Ir}(\mathrm{ppy}) 3-\beta-\mathrm{Ala}-\mathrm{COOH}, \mathrm{DCC}, \mathrm{NHS}, \mathrm{H}_{2} \mathrm{O} / \mathrm{DMSO}$. The amino acid sequence for cleavage is highlighted in red and comprised of either L-amino acid or D-amino acids. All other amino acids used to generate these structures were D-amino acids.

\subsection{Synthesis of Cy3-Cy5 Peptides (2L and 2D)}

1L (1.4 mg, $0.42 \mu \mathrm{mol})$ was dissolved in $4 \mathrm{~mL}$ dry DMSO and DIPEA (5 $\mu \mathrm{L}, 28 \mu \mathrm{mol})$ was added. Cy3-NHS ( $1 \mathrm{mg}, 1.2 \mu \mathrm{mol})$ was dissolved in $100 \mu \mathrm{L}$ dry DMSO and added to the reaction mixture. The mixture was stirred at RT for 7 days, after which the product was purified by HPLC. The product peak was collected and lyophilized to give a purple solid (2L, $0.3 \mathrm{mg}, 18 \%$ ). $\mathrm{m} / \mathrm{z}$ (MALDI-ToF): $\left[\mathrm{C}_{171} \mathrm{H}_{271} \mathrm{~N}_{50} \mathrm{O}_{50} \mathrm{~S}_{6}\right]^{+}$calcd 4019.7, found 4020.2. 
$1 D(0.6 \mathrm{mg}, 0.19 \mu \mathrm{mol})$ was dissolved in $1 \mathrm{~mL}$ DMSO and $2 \mathrm{~mL} 0.1 \mathrm{M}$ phosphate buffer $\mathrm{pH} 8.0$ (no further base was added since this would increase the likelihood of hydrolysis). Cy3-NHS (0.8 mg, $1.0 \mu \mathrm{mol})$ was dissolved in dry DMSO added to the reaction mixture. Work-up was similar to $2 \mathbf{L}$ to give 2D (0.3 mg, 39\%). m/z (MALDI-ToF): [ $\left.\mathrm{C}_{171} \mathrm{H}_{271} \mathrm{~N}_{50} \mathrm{O}_{50} \mathrm{~S}_{6}\right]^{+}$calcd 4019.7, found 4020.7 .

\subsection{Synthesis of $\operatorname{Ir}(p p y){ }_{3}-C y 5$ Peptides (3L and 3D)}

$\operatorname{Ir}(\mathrm{ppy}){ }_{3}-\mathrm{COOH}(5.4 \mathrm{mg}, 7 \mu \mathrm{mol})$, synthesized as previously described [32], was dissolved in $500 \mu \mathrm{L}$ DMSO. To this solution was added NHS $(1.2 \mathrm{mg}, 10 \mu \mathrm{mol})$ and DCC (1.2 $\mathrm{mg}, 6 \mu \mathrm{mol})$ and the reaction was stirred for $15 \mathrm{~min}$ at RT to form $\operatorname{Ir}(\mathrm{ppy})_{3}-\mathrm{NHS}$ in situ.

Three hundred microlitres of the freshly made solution of $\operatorname{Ir}(\mathrm{ppy}){ }_{3}-\mathrm{NHS}(4.2 \mu \mathrm{mol})$ was added to a solution of 2 (L: $5.1 \mathrm{mg}, 1.5 \mu \mathrm{mol}$; D: $1.4 \mathrm{mg}, 0.4 \mu \mathrm{mol}$ ) in $500 \mu \mathrm{L}$ phosphate buffer (pH 8.0). The solution was stirred overnight at RT, and a precipitation formed. This precipitate was redissolved and purified by HPLC. The product peak was collected and lyophilized to give a blue-green solid. The yield of $3 \mathrm{~L}$ was determined by UV/Vis to be $5.1 \mathrm{nmol}(<1 \%) . \mathrm{m} / z$ (MALDI-ToF): $\left[\mathrm{C}_{175} \mathrm{H}_{258} \mathrm{IrN}_{52} \mathrm{O}_{42} \mathrm{~S}_{3}\right]^{+}$ calcd 4050.7, found 4052.4. The yield of 3D was $3.8 \mathrm{nmol}(<1 \%) . \mathrm{m} / \mathrm{z}$ (MALDI-ToF): $\left[\mathrm{C}_{175} \mathrm{H}_{258} \mathrm{IrN}_{52} \mathrm{O}_{42} \mathrm{~S}_{3}\right]$ calcd 4050.7, found 4047.8.

\subsection{Spectroscopic Measurements}

All spectroscopic measurements were performed in quartz cuvettes. UV-Vis measurements were performed on an Amersham Ultrospec 3000. Emission spectra were measured using a Perkin Elmer S55. For fluorescence measurements, the absorbance was kept below 0.1 to prevent inner filter effects. Luminescence lifetime measurements were carried out using time-correlated single photon counting on a F900 Spectrometer (Edinburgh Instruments, Livingston, UK). For this, $\operatorname{Ir}(\mathrm{ppy}))_{3}$ compounds (3L and 3D) were dissolved in phosphate buffered saline (PBS) and excited using a picosecond pulsed diode laser (PicoQuant LDH-P-C-375, $372 \mathrm{~nm}$ ) operated at 2.5 MHz. Luminescence emission was detected at $600 \mathrm{~nm}$ on a microchannel plate detector. Lifetimes were fit to a biexponential decay model using one long lifetime of $100 \mathrm{~ns}$ and one short lifetime of $1.0 \mathrm{~ns}$.

\subsection{Calculation of Distances between Luminophores}

Distances between Cy3 and Cy5 were estimated using Equation (1) [33]. Peak intensities at $566 \mathrm{~nm}$ were used, and $R_{0}$ was set as $53 \AA$ [34].

$$
1-\frac{F_{D A}}{F_{D}}=\frac{R_{0}^{6}}{R_{0}^{6}+r^{6}}
$$

$F_{D A}=$ Fluorescence intensity of donor in the presence of acceptor; $F_{D}=$ Fluorescence intensity of donor emission in the absence of acceptor; $R_{0}$ Forster radius; $r=$ distance between donor and acceptor.

Distances between $\operatorname{Ir}(\text { ppy })_{3}$ and Cy5 were estimated using Equation (2) [33], and $R_{0}$ was set as $48 \AA$ [29].

$$
1-\frac{\tau_{D A}}{\tau_{D}}=\frac{R_{0}^{6}}{R_{0}^{6}+r^{6}}
$$


$\tau_{D A}=$ Luminescence lifetime of donor in the presence of acceptor; $\tau_{D}=$ Luminescence lifetime of donor in the absence of acceptor; $R_{0}$ Forster radius; $r=$ distance between donor and acceptor.

\subsection{Enzymatic Peptide Cleavage by Cells in Suspension}

The individual imaging agents (2L, 2D, 3L, 3D) were dissolved in $2 \mathrm{~mL}$ buffer $(100 \mathrm{mM} \mathrm{NaCl}$, $10 \mathrm{mM} \mathrm{CaCl}_{2}, 50 \mu \mathrm{M} \mathrm{ZnCl}_{2}, 50 \mathrm{mM}$ Tris, $\mathrm{pH} 7.1$ ) in a quartz cuvette to create a $0.2 \mu \mathrm{M}$ solution. To this $2.0 \times 10^{4} \mathrm{SKOV}-3$ cells in $500 \mu \mathrm{L}$ DMEM were added. Enzymatic assays were performed at $37{ }^{\circ} \mathrm{C}$ to mimic physiological conditions as much as possible. Fluorescence spectra of the compounds were measured with intervals of $1-2 \mathrm{~h}$ up to $24 \mathrm{~h}$ to monitor the cleavage process.

For 2L and 2D, spectra were measured by excitation at $525 \mathrm{~nm}$ (Cy3 excitation), while the emission was detected between 540 and $750 \mathrm{~nm}$. For 3L and 3D, $\operatorname{Ir}(\text { ppy })_{3}$ spectra were measured by excitation at $450 \mathrm{~nm}$, and emission detection was measured between 480 and $750 \mathrm{~nm}$. Cy5 spectra (3L, 3D) were measured using excitation at $625 \mathrm{~nm}$, and emission detection between 640 and $750 \mathrm{~nm}$.

\subsection{Enzymatic Peptide Cleavage by Adherent Cells}

The MMP-2/9 expressing human ovary cancer cell line SKOV-3 [35] was maintained in Dulbecco's minimum essential medium (DMEM) enriched with 10\% fetal bovine serum and $5 \mathrm{~mL}$ Penicillin/Streptomycin (10,000 units/mL Penicillin; 10,000 $\mu \mathrm{g} / \mathrm{mL}$ Streptomycin) (all Life Technologies Inc., Breda, The Netherlands). Cells were kept under standard culture conditions. The cells were grown on a glass-bottom well, after which they were incubated at $37^{\circ} \mathrm{C}$ in a solution of an activatable imaging agent in DMEM for $24 \mathrm{~h}(0.2 \mu \mathrm{M}$ for $\mathbf{2 L}$ and $\mathbf{2 D}$; $0.5 \mu \mathrm{M}$ for $\mathbf{3 L}$ and $\mathbf{3 D})$. After incubation, cells were thoroughly washed with PBS. No negative effects of the compounds on cell growth were observed.

\subsection{Confocal Imaging}

After incubation, live cell images were taken on a Leica SP5 confocal microscope under $63 \times$ magnification. Ir(ppy) 3 luminescence was measured using $458 \mathrm{~nm}$ excitation (Ar laser line) and emission was collected between 560 and $620 \mathrm{~nm}$. Cy3 fluorescence was measured using $514 \mathrm{~nm}$ excitation (Ar laser line) and the emission was collected between 550 and $600 \mathrm{~nm}$. Cy5 fluorescence was measured using excitation at $633 \mathrm{~nm}$ (HeNe laser) and the emission was collected between 650 and $700 \mathrm{~nm}$.

\subsection{Fluorescence Lifetime Imaging Microscopy}

FD-FLIM images of SKOV-3 cells incubated with 3L or 3D $(0.5 \mu \mathrm{M}, 24 \mathrm{~h})$ were obtained with LI-FLIM hardware (Lambert Instruments, Roden, The Netherlands) and software (v.1.2.23.59) with a modulated GaAs intensifier fiber-optically coupled to a digital CCD-camera ( $\mathrm{LI}^{2} \mathrm{CAM}$, Lambert Instruments) attached to the microscope (Leica DMIRE2; Leica Microsystems, Heidelberg, Germany) with a $63 \times$ objective (numerical aperture 1.3, glycerine-immersion). A 1-W, 442-nm LED was modulated at $1 \mathrm{MHz}$, and light passed a CFP/YFP filtercube (excitation 436/12 \& 500/20, dichroic $445 \& 515$, emission $467 / 37$ \& 545/45). Rhodamine $6 \mathrm{G}$ in $\mathrm{H}_{2} \mathrm{O}$ was used as reference $\left(\tau_{\text {phase: }} 3.83 \mathrm{~ns}\right.$ at $37{ }^{\circ} \mathrm{C}$ ) (Sigma-Aldrich, St. Louis, MO, USA). The cells were placed in preheated $\left(37^{\circ} \mathrm{C}\right) 4$-(2-hydroxyethyl)1-piperazineethane-sulfonic acid (HEPES)-buffered saline (140 mM NaCl, $5 \mathrm{mM} \mathrm{KCl,} 1 \mathrm{mM} \mathrm{MgCl}$, 
$1 \mathrm{mM} \mathrm{CaCl}_{2}, 10 \mathrm{mM}$ glucose, and $10 \mathrm{mM}$ HEPES, $\mathrm{pH}$ 7.4) after washing with PBS. All experiments were performed at $37^{\circ} \mathrm{C}$.

\section{Results and Discussion}

\subsection{Design and Synthesis of the Imaging Agents}

Use of a hairpin motive is a known method to bring two luminophores within close proximity of each other and has already proven to be of value for the detection of thrombin [36] and MMP-2/9 [37]. In the hairpin motive used in our study, the electrostatic interactions between the positively charged arginine residues and the negatively charged glutamic acid residues ensure conformational rigidity, while leaving the cleavage site freely available for the MMP-2/9 enzymes (Figure 1) [15]. To prevent non-specific cleavage (e.g., by other peptidases), except for the cleavage site, the hairpin motive was generated out of D-amino acids.

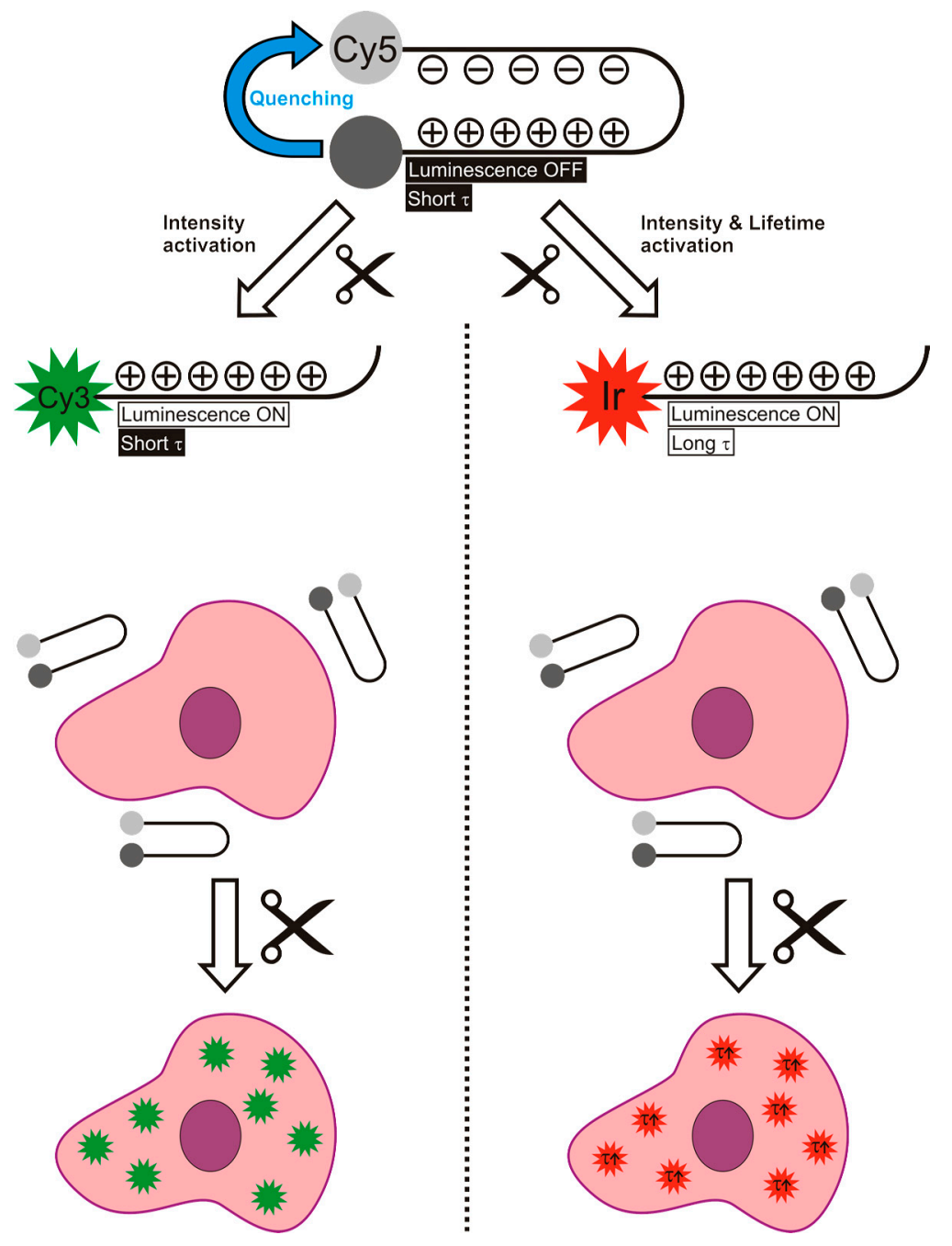

Figure 1. Schematic overview of the difference between the use of an activatable luminescence imaging agent (left) and an activatable lifetime imaging agents (right), both based on a hairpin motive. It is important to note that in the case of lifetime activation not only the intensity increases, but also the lifetime. This gives two parameters to follow the activation reaction. 
The synthesis of all agents was successful. Labeling of the D \& L hairpin motive peptides with Cy5 resulted in yields of $87 \%$ (1L) and $36 \%$ (1D). Generation of the reference compounds containing Cy3 and Cy5 gave reasonable yields of $18 \%$ (2L) and 39\% (2D). The relatively poor solubility of 1 in DMSO proved to be limiting for the reaction to occur. In fact, for the synthesis of $\mathbf{2 D}$, the solvent of the reaction was changed to a water/DMSO mixture, despite the risk of hydrolyzing Cy3-NHS. It proved to be more difficult to obtain the imaging agents containing $\operatorname{Ir}(\mathrm{ppy})_{3}$ and $\mathrm{Cy} 5, \mathbf{3 L}$ and 3D, resulting in very low yields of $<1 \%$, which was, however, enough to perform proof-of-concept studies. Ir(ppy)3-NHS had to be synthesized in situ and directly used, since the activated ester was not soluble in water and its purification was cumbersome. As one may realize, this increased the solubility issues even further. To still allow for a reaction to take place, $\operatorname{Ir}(\mathrm{ppy})_{3}$-NHS (in DMSO) had to be added quickly to a stirring solution of 1 in aqueous solution (phosphate buffer $\mathrm{pH}$ 8.0). These non-ideal conditions resulted in precipitation of compounds and a large amount of hydrolysis of the active ester. Given our focus on the utility of the compounds generated, no further attempts were made to optimize the yields.

\subsection{Photophysical Analysis of the Imaging Agents}

In the reference compounds $\mathbf{2} \mathbf{L}$ and $\mathbf{2 D}$, the close proximity of the donor (Cy3) and acceptor (Cy5) yielded a very clear FRET interaction, as expected [34,38]. In the excitation-emission plots, a peak that corresponds to donor excitation $(550 \mathrm{~nm})$ and acceptor emission $(670 \mathrm{~nm})$ can be seen for both compounds (Figure 2A,B). However, there are clear differences in quenching efficiency between $\mathbf{2 L}$ (43\% quenching) and 2D ( $88 \%$ quenching) (Figure 2). Based on the fluorescence intensities, we calculated the Cy3-Cy5 distances to be $53 \AA$ for $\mathbf{2 L}$ and $38 \AA$ for $2 \mathbf{D}$. This difference in calculated distance between the dyes can be caused by a slightly different structural configuration of the hairpin structure with the D-amino acids compared to the one with L-amino acids. Since FRET efficiency depends to the sixth power on the donor-acceptor distance, these relatively small differences in the hairpin configuration may explain the much larger differences in FRET efficiency. Another possibility is that the difference in amino acid stereochemistry leads to a difference in dipole orientation. This also has a pronounced effect on the correct calculation of the distances [33].
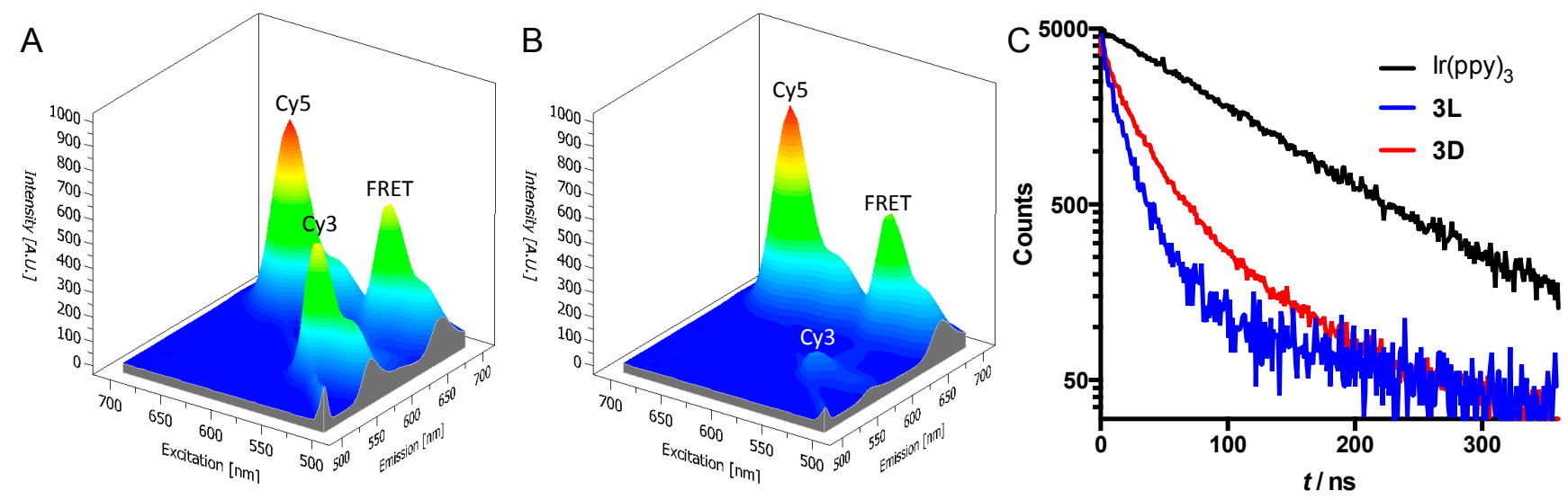

Figure 2. (A,B) Excitation-emission plots of peptides 2L (A) and 2D (B). The peaks labeled as "FRET" are the peaks that show acceptor emission $(670 \mathrm{~nm})$ with donor excitation $(550 \mathrm{~nm})$; (C) Luminescence decay traces at $600 \mathrm{~nm}$ of $\mathbf{3 L}, \mathbf{3 D}$, and reference compound $\operatorname{Ir}\left(\right.$ ppy) ${ }_{3}-\mathrm{COOH}$ in water. All compounds were excited with a $372 \mathrm{~nm}$ laser at $2.5 \mathrm{MHz}$. 
For peptides 3L and 3D, no FRET signals could be detected using the spectrometer. In fact, emissions of both $\operatorname{Ir}(\text { ppy })_{3}$ and Cy 5 were efficiently quenched. This indicates that the earlier-described double quenching interactions between Cy5 and $\operatorname{Ir}($ ppy) 3 are also applicable in this hairpin structure $[25,29]$. In short: emission from $\operatorname{Ir}(\mathrm{ppy})_{3}$ is quenched by FRET to Cy5, while the Ir atom causes quenching of Cy5 emission. The emission of Cy5 was quenched very efficiently in peptides 3L and 3D, with a quenching efficiency of $91 \%-92 \%$ for both compounds compared to pure Cy5. The average lifetime of $\operatorname{Ir}($ ppy) 3 emission in the peptides (30 ns for 3L and $43 \mathrm{~ns}$ for 3D) was measured to be clearly different from that of pure $\operatorname{Ir}(\mathrm{ppy})_{3}-\mathrm{COOH}$ (98 ns, Figure 2C). This reduction of lifetime of $\operatorname{Ir}(\mathrm{ppy}) 3$ is indicative for a quenching interaction between both luminophores [33].

$\operatorname{Ir}(\mathrm{ppy})_{3}$-Cy5 distance calculations based on emission intensities proved to be inaccurate due to the low signal intensities. Instead, donor-acceptor distances were estimated based on the luminescence lifetime [33]. This gave distances between $\operatorname{Ir}(\text { ppy) })_{3}$ and Cy5 of $42 \AA$ for $3 \mathbf{L}$ and $46 \AA$ for 3D. These distances are in the same order as the distances estimated for $\mathbf{2 L}$ and $\mathbf{2 D}$. Although these distances are generally considered to be too long for efficient spin-orbit coupling [39], still efficient Cy5 quenching was observed. This might indicate that a different quenching mechanism could be responsible for the quenching of Cy5 by $\operatorname{Ir}($ ppy) 3 ; potential candidates include static quenching, excimer formation or photoinduced electron transfer $[33,40]$.

\subsection{Enzymatic Cleavage Assay by Cells in Suspension}

We investigated the enzymatic activity of live tumor cells towards the activatable imaging agents (2 and 3) using fluorescence spectroscopy. For this, SKOV-3 human ovary adenocarcinoma cells were chosen since they are known to express MMP-2/9 [35]. The imaging agents were added to the cells in suspension and the reaction was followed by measuring fluorescence emission spectra. The rationale behind these experiments is that the ratio between donor and acceptor emission intensity upon donor excitation provides a read-out that is independent of concentration [36]. As a result, this value provides a more quantitative read-out of the activation assay than the individual signal intensities. Hereby, it has to be taken into account that the ratio between donor and acceptor emission is influenced by both an increase in donor emission and a decrease in acceptor emission, meaning that the cleavage is effectively counted double in the donor/acceptor ratio.

In $\mathbf{2 L}$, enzymatic cleavage resulted in a simultaneous increase in donor emission (566 $\mathrm{nm})$ and decrease in acceptor emission (666 nm) (Figure 3A-C). In contrast, 2D (the control) revealed no alterations when exposed to the enzymes, underlining that the D-amino acids do not get cleaved. This is exactly like expected for the enzymatically induced disruption of the FRET donor-acceptor pair in $2 \mathbf{L}$. In numbers, the intensity ratio $\mathrm{Cy} 3 / \mathrm{Cy} 5$ of $\mathbf{2} \mathbf{L}$ showed an eight-fold increase after cleavage, going from 0.9 to 7.7 . In contrast, the compound with D-amino acids on the cleavage site (2D) only went from 0.22 to 0.27 after $24 \mathrm{~h}$.

Similar to what we observed for peptides 2, cleavage of lifetime imaging agents 3 resulted in an increase in donor-acceptor distance. The spin-orbit coupling that caused the quenching of the Cy5 emission is nullified after cleavage of peptide 3L. This resulted in a four-fold increase of Cy5 emission in time, while the control compound 3D only showed a 1.1-fold increase after $18 \mathrm{~h}$ (Figure 3E,F). The increase in $\operatorname{Ir}(\text { ppy })_{3}$ emission was only minimal (Figure 3D). This can be explained by cellular uptake 
of the activated cell penetrating peptide that is formed after cleavage [15]. The combination of the many positive charges from the arginine residues with the lipophilicity of the $\operatorname{Ir}(\mathrm{ppy}) 3$ creates a compound that is easily taken up by cells. This uptake effectively reduces $\operatorname{Ir}($ ppy) 3 concentration in the solution, which gives a flawed representation of activation. Apparently, the hydrophilicity and negative charges on $\mathrm{Cy} 3$ on $\mathbf{2} \mathbf{L}$ partly prevented cellular uptake, since Cy3 activation was visible in solution. As a result, the ratio between donor and acceptor emission in $\operatorname{Ir}(\mathrm{ppy})_{3}-\mathrm{Cy} 5$ imaging agents cannot be used for signal quantification, since both donor and acceptor intensity increase in time.
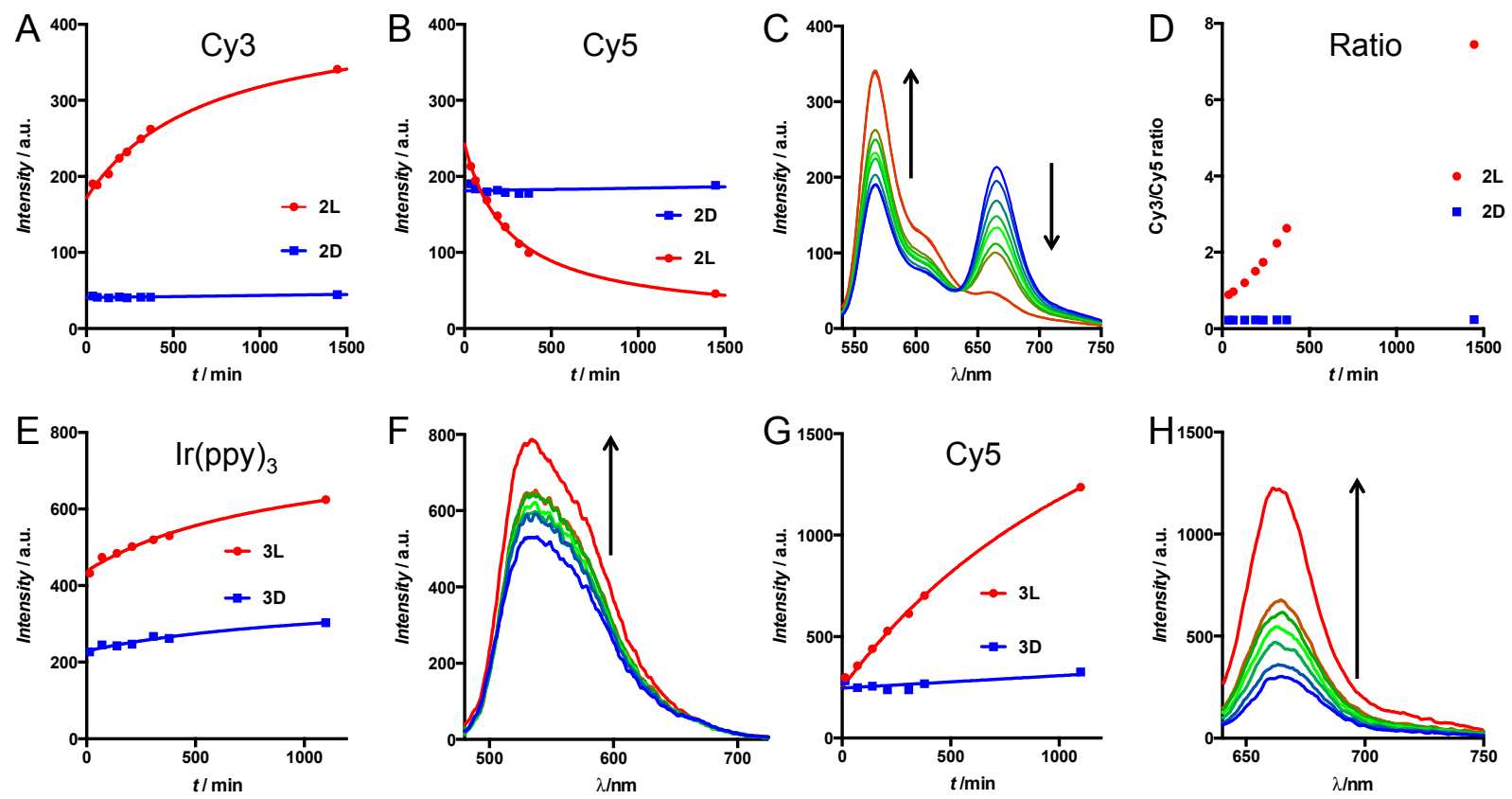

Figure 3. (A-D) Cleavage assay of $\mathbf{2 L}$ and $2 \mathbf{D}$ by MMP-expressing cells $(\mathbf{A}, \mathbf{B})$ Emission intensity from peptides $\mathbf{2 L}$ (red circles) and 2D (blue squares) of the donor peak (Cy3, excitation $525 \mathrm{~nm}$, emission $566 \mathrm{~nm}$ ) (A) and the FRET peak (Cy5, excitation $525 \mathrm{~nm}$, emission $666 \mathrm{~nm}$ ) (B) in time; (C) Variations in emission spectra (excitation $525 \mathrm{~nm}$ ) of $\mathbf{2} \mathbf{L}$ in time from blue (first time point) to red (last time point) and (D) the donor/acceptor ratio; $(\mathbf{E}-\mathbf{H})$ Cleavage assay of $\mathbf{3 L}$ and $\mathbf{3 D}$ by MMP-expressing cells; (E,G) Emission intensity changes from peptides 3L (red circles) and 3D (blue squares) of the peaks at $590 \mathrm{~nm}(\mathbf{E})$ and $666 \mathrm{~nm}(\mathbf{G})$ in time; $(\mathbf{F}, \mathbf{H})$ Change in emission of these peaks of $3 \mathbf{L}$ in time from blue (first time point) to red (last time point) with excitation at $420 \mathrm{~nm}$ (F) or $625 \mathrm{~nm}(\mathbf{H})$. Arrows indicate change in time.

\subsection{Enzymatic Cleavage Assay Followed by Microscopy}

After successful cleavage of the activatable imaging agents by cells in suspension, SKOV-3 cells were grown on a glass slide and incubated in vitro with $\mathbf{2 L}$ and $\mathbf{2 D}$. Confocal microscopy was used to examine the cleavage activity after $24 \mathrm{~h}$ of incubation. Just as it was observed for the cleavage in suspension (Figure 3), peptide $\mathbf{2 L}$ yielded an activated donor (Cy3) emission, which was not detected for 2D (Figure 4B,E). The emission of Cy5 was used as a control, since the acceptor fluorescence upon direct acceptor excitation is not affected by the presence or absence of the Cy3 donor. Cy5 intensities of 2L and 2D were similar (Figure 4A,D). 


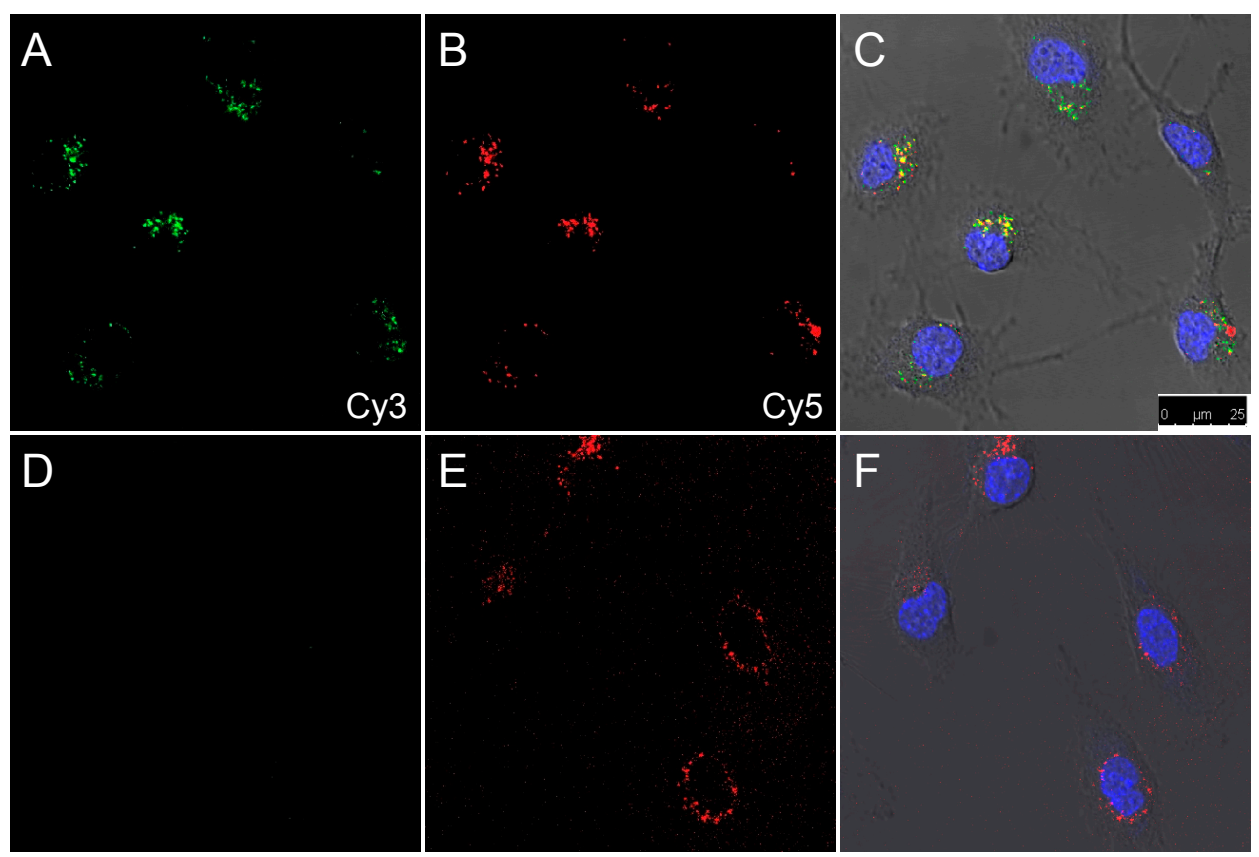

Figure 4. Confocal images of SKOV-3 cells after $24 \mathrm{~h}$ incubation with $2 \mathrm{~L}(\mathbf{A}-\mathbf{C})$ or 2D (D-F). (A,D) Cy3 channel in green; (B,E) Cy5 channel in red; (D,F) Overlay of differential interference contrast, nuclear stain (Hoechst 33342, blue), Cy3 (green), and Cy5 (red). Excitation and emission wavelengths are described in the Experimental Section.

The activation of compounds 3L and 3D was also tested using confocal microscopy. After $24 \mathrm{~h}$ incubation of SKOV-3 cells with either compound, signals of both $\operatorname{Ir}(\mathrm{ppy})_{3}$ and Cy5 were observed (Figure 5). Compound 3L showed bright signals of both luminophores inside the cells, indicating successful cleavage of the activatable imaging agent 3L in vitro. In contrast, in 3D the emission intensities of both luminophores were very weak, possibly due to non-specific cleavage by other enzymes. Nuclear staining with Hoechst was not possible due to spectral overlap with $\operatorname{Ir}(\mathrm{ppy}) 3$.
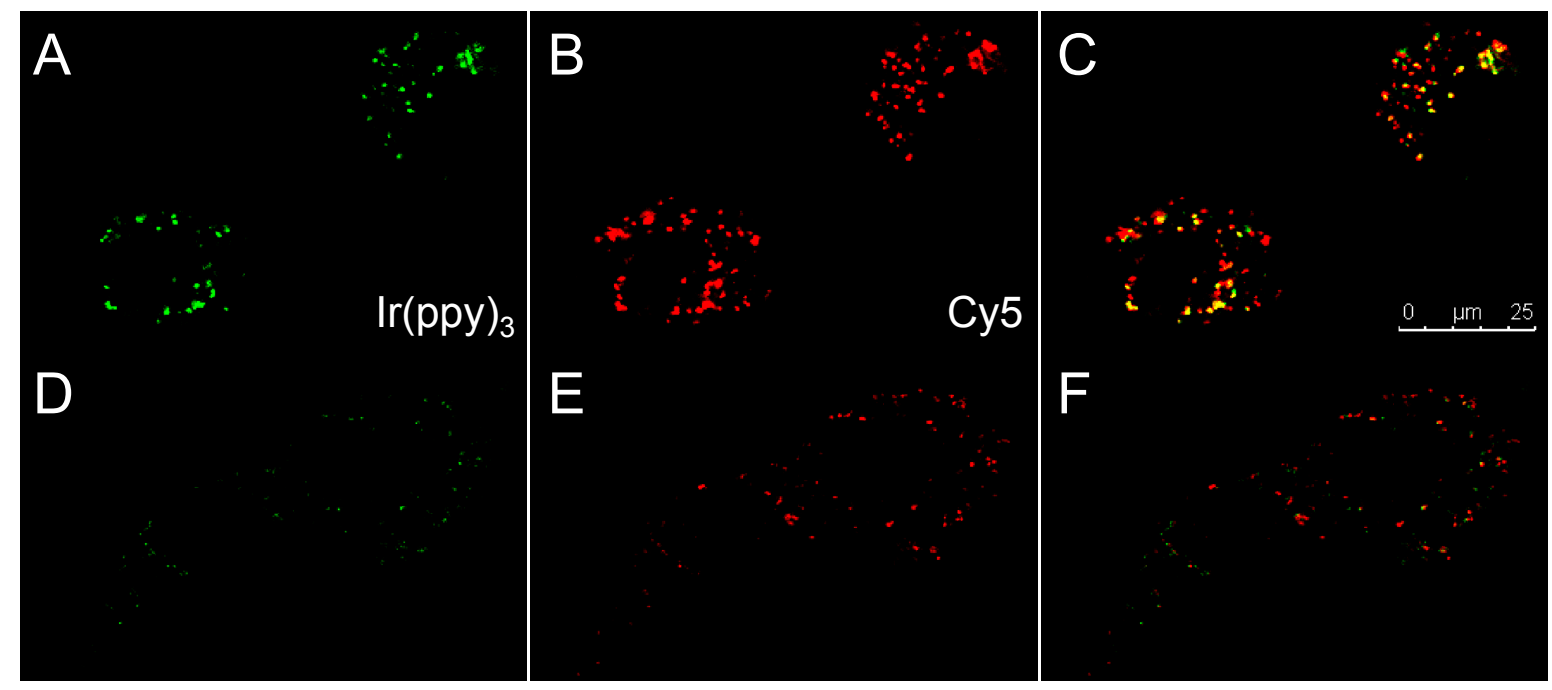

Figure 5. Confocal images of SKOV-3 cells after $24 \mathrm{~h}$ incubation with $\mathbf{3 L}(\mathbf{A}-\mathbf{C})$ or 3D (D-F). (A,D) $\operatorname{Ir}\left(\right.$ ppy) ${ }_{3}$ channel in green; $(\mathbf{B}, \mathbf{E})$ Cy5 channel in red; $(\mathbf{C}, \mathbf{F})$ Overlay of both channels. Yellow means colocalization of red and green. 
Lifetimes were also used to measure the cleavage reaction in suspension. Since the initial signal intensities of the quenched starting point were very weak, long measurement times ( $>3 \mathrm{~h}$ per sample) were necessary to provide reliable lifetimes. This made dynamic measurements during the cleavage reaction impossible. Therefore, we measured the luminescence lifetime of $\mathbf{3 L}$ and $\mathbf{3 D}$ only after the cleavage reaction was complete (Figure 6A). Again, the uptake of the polycationic $\operatorname{Ir}($ ppy)3 peptide caused low concentration of $\operatorname{Ir}(\mathrm{ppy})_{3}$ in solution, making lifetime measurements even more difficult. The only conclusion that can be drawn from these measurements is that there is relatively more long-lifetime activated $\operatorname{Ir}(\mathrm{ppy})_{3}$ present after incubation of 3L compared to 3D (Figure 6A).
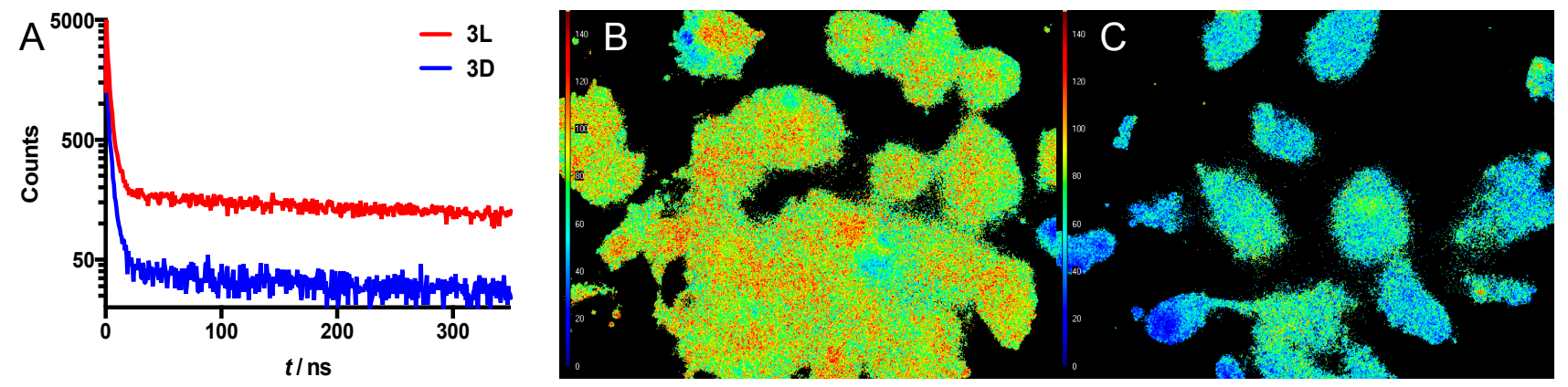

Figure 6. (A) Luminescence decay traces of a suspension of SKOV-3 cells after $24 \mathrm{~h}$ incubation with 3L (red) or 3D (blue); (B) FLIM image of cells incubated with 3L; (C) FLIM image of cells incubated with 3D. The scalebar on the left depicts $\tau$, going from $0 \mathrm{~ns}$ (blue) to $150 \mathrm{~ns}$ (red).

The potential of this new activatable lifetime imaging agent for Fluorescencence Lifetime Imaging Microscopy (FLIM) is shown in Figure 6B,C. After incubation of SKOV-3 cells with either compound 3L or 3D (24 h), the average lifetime of each pixel of the microscopy image was measured. From that, the average lifetime of the luminescence signal from cells was determined. For $\mathbf{3 L}$, the cleavable version, the average lifetime was $94 \mathrm{~ns}$, while the control compound 3D gave a substantially different average lifetime of $57 \mathrm{~ns}$. These values are only slightly different from the respective lifetimes measured in solution, $98 \mathrm{~ns}\left(\operatorname{Ir}(\text { ppy)})_{3}\right)$ and 43ns (3D), respectively (see above). Based on the similarity in the spectroscopic measurements findings and the FLIM measurements, we feel confident that luminescence lifetime has provided a quantifiable readout for the MMP-2/9 induced activation of 3L. This is the second time that we have shown the value of the $\operatorname{Ir}(\mathrm{ppy})_{3}-\mathrm{Cy} 5$ combination for activatable luminescence lifetime imaging, indicating that this combination has potential in different chemical formulations. Hence, it may also provide value in other-FRET based-designs for activatable imaging agents [41], thereby generating added value for the quantification of different disease related features. As alluded to in the introduction, a reduction in autofluorescence and thus non-specific background signal may be achieved using the concept of activatable lifetime imaging. In this concept, the sensitivity of enzymatically activated luminescence intensification can be strengthened further by enzymatically activated lifetime prolongation. This effect combined with a disease specific enzyme may help increase signal-to-background ratios between healthy and diseased tissue in vitro or in the future possibly also in vivo. The latter may help provide new imaging concepts in the field of luminescence-based interventional molecular imaging [42]. 


\section{Conclusions}

To conclude, FRET-based activatable imaging agents for the tumor-specific enzymes MMP-2/9 not only show potential for activatable luminescence imaging, in combination with $\operatorname{Ir}(\mathrm{ppy})_{3}$, this concept can now even be extended to the field of (microscopic) luminescence lifetime imaging.

\section{Acknowledgments}

This research was supported by an NWOnano-Grant (STW 11435; F.v.L.), a Netherlands Organisation for Scientific Research VIDI grant (STW BGT 11272; F.v.L.). The research leading to these results has also received funding from the European Research Council under the European Union's Seventh Framework Programme (FP7/2007-2013) ERC grant agreement n 2012-306890. The authors would like to thank A. Bunschoten, D. van Willigen and P. Steunenberg for kindly supplying compounds.

\section{Author Contributions}

M.T.M. Rood and F.W.B. van Leeuwen designed the experiments. M.T.M. Rood synthesized all compounds and performed the cell studies. J.B. ten Hove performed lifetime measurements. M. Raspe and K. Jalink performed FLIM experiments. A.H. Velders and F.W.B. van Leeuwen supervised the project.

\section{Conflicts of Interest}

The authors declare no conflict of interest.

\section{References}

1. Rao, J.; Dragulescu-Andrasi, A.; Yao, H.; Yao, H. Fluorescence imaging in vivo: Recent advances. Curr. Opin. Biotechnol. 2007, 18, 17-25.

2. Monici, M. Cell and tissue autofluorescence research and diagnostic applications. Biotechnol Annu Rev. 2005, 11, 227-256.

3. Billinton, N.; Knight, A.W. Seeing the wood through the trees: A review of techniques for distinguishing green fluorescent protein from endogenous autofluorescence. Anal. Biochem. 2001, 291, 175-197.

4. Berezin, M.Y.; Achilefu, S. Fluorescence lifetime measurements and biological imaging. Chem. Rev. 2010, 110, 2641-2684.

5. Hennig, A.; Roth, D.; Enderle, T.; Nau, W.M. Nanosecond time-resolved fluorescence protease assays. Chembiochem 2006, 7, 733-737.

6. Maliwal, B.P.; Fudala, R.; Raut, S.; Kokate, R.; Sorensen, T.J.; Laursen, B.W.; Gryczynski, Z.; Gryczynski, I. Long-lived bright red emitting azaoxa-triangulenium fluorophores. PLoS ONE 2013, 8, e63043. 
7. Rich, R.M.; Stankowska, D.L.; Maliwal, B.P.; Sorensen, T.J.; Laursen, B.W.; Krishnamoorthy, R.R.; Gryczynski, Z.; Borejdo, J.; Gryczynski, I.; Fudala, R. Elimination of autofluorescence background from fluorescence tissue images by use of time-gated detection and the azadioxatriangulenium (adota) fluorophore. Anal. Bioanal. Chem. 2013, 405, 2065-2075.

8. Ruggi, A.; van Leeuwen, F.W.B.; Velders, A.H. Interaction of dioxygen with the electronic excited state of $\operatorname{Ir}($ iii) and $\mathrm{Ru}$ (ii) complexes: Principles and biomedical applications. Coord. Chem. Rev. 2011, 255, 2542-2554.

9. Ruggi, A.; Beekman, C.; Wasserberg, D.; Subramaniam, V.; Reinhoudt, D.N.; van Leeuwen, F.W.B.; Velders, A.H. Dendritic ruthenium(ii)-based dyes tuneable for diagnostic or therapeutic applications. Chemistry 2011, 17, 464-467.

10. Kuil, J.; Steunenberg, P.; Chin, P.T.K.; Oldenburg, J.; Jalink, K.; Velders, A.H.; van Leeuwen, F.W.B. Peptide-functionalized luminescent iridium complexes for lifetime imaging of cxcr4 expression. Chembiochem 2011, 12, 1896-1902.

11. Longmire, M.; Choyke, P.L.; Kobayashi, H. Clearance properties of nano-sized particles and molecules as imaging agents: Considerations and caveats. Nanomedicine 2008, 3, 703-717.

12. Lovell, J.F.; Zheng, G. Activatable smart probes for molecular optical imaging and therapy. J. Innov. Opt. Health Sci. 2008, 1, 45-61.

13. Johnson, J.R.; Kocher, B.; Barnett, E.M.; Marasa, J.; Piwnica-Worms, D. Caspase-activated cell-penetrating peptides reveal temporal coupling between endosomal release and apoptosis in an rgc-5 cell model. Bioconjug. Chem. 2012, 23, 1783-1793.

14. Urano, Y.; Sakabe, M.; Kosaka, N.; Ogawa, M.; Mitsunaga, M.; Asanuma, D.; Kamiya, M.; Young, M.R.; Nagano, T.; Choyke, P.L.; et al. Rapid cancer detection by topically spraying a gamma-glutamyltranspeptidase-activated fluorescent probe. Sci. Transl. Med. 2011, 3, 110ra119, doi:10.1126/scitranslmed.3002823.

15. Jiang, T.; Olson, E.S.; Nguyen, Q.T.; Roy, M.; Jennings, P.A.; Tsien, R.Y. Tumor imaging by means of proteolytic activation of cell-penetrating peptides. Proc. Natl. Acad. Sci. USA 2004, 101, 17867-17872.

16. Akers, W.J.; Xu, B.; Lee, H.; Sudlow, G.P.; Fields, G.B.; Achilefu, S.; Edwards, W.B. Detection of mmp-2 and mmp-9 activity in vivo with a triple-helical peptide optical probe. Bioconjug. Chem. 2012, 23, 656-663.

17. Lee, S.; Park, K.; Kim, K.; Choi, K.; Kwon, I.C. Activatable imaging probes with amplified fluorescent signals. Chem. Commun. 2008, 4250-4260.

18. Zlokarnik, G.; Negulescu, P.A.; Knapp, T.E.; Mere, L.; Burres, N.; Feng, L.X.; Whitney, M.; Roemer, K.; Tsien, R.Y. Quantitation of transcription and clonal selection of single living cells with beta-lactamase as reporter. Science 1998, 279, 84-88.

19. Dorokhin, D.; Hsu, S.H.; Tomczak, N.; Blum, C.; Subramaniam, V.; Huskens, J.; Reinhoudt, D.N.; Velders, A.H.; Vancso, G.J. Visualizing resonance energy transfer in supramolecular surface patterns of beta-cd-functionalized quantum dot hosts and organic dye guests by fluorescence lifetime imaging. Small 2010, 6, 2870-2876.

20. Kobayashi, H.; Choyke, P.L. Target-cancer-cell-specific activatable fluorescence imaging probes: Rational design and in vivo applications. Acc. Chem. Res. 2011, 44, 83-90. 
21. Dorokhin, D.; Hsu, S.H.; Tomczak, N.; Reinhoudt, D.N.; Huskens, J.; Velders, A.H.; Vancso, G.J. Fabrication and luminescence of designer surface patterns with beta-cyclodextrin functionalized quantum dots via multivalent supramolecular coupling. ACS Nano 2010, 4, 137-142.

22. Jun, M.E.; Roy, B.; Ahn, K.H. "Turn-on" fluorescent sensing with "reactive" probes. Chem. Commun. 2011, 47, 7583-7601.

23. Garcia-Beltran, O.; Mena, N.; Berrios, T.A.; Castro, E.A.; Cassels, B.K.; Nunez, M.T.; Aliaga, M.E. A selective fluorescent probe for the detection of mercury (ii) in aqueous media and its applications in living cells. Tetrahedron Lett. 2012, 53, 6598-6601.

24. Drake, C.R.; Miller, D.C.; Jones, E.F. Activatable optical probes for the detection of enzymes. Curr. Org. Synth. 2011, 8, 498-520.

25. Aguilera, T.A.; Olson, E.S.; Timmers, M.M.; Jiang, T.; Tsien, R.Y. Systemic in vivo distribution of activatable cell penetrating peptides is superior to that of cell penetrating peptides. Integr. Biol. 2009, 1, 371-381.

26. Kessenbrock, K.; Plaks, V.; Werb, Z. Matrix metalloproteinases: Regulators of the tumor microenvironment. Cell 2010, 141, 52-67.

27. Westermarck, J.; Kahari, V.M. Regulation of matrix metalloproteinase expression in turner invasion. FASEB J. 1999, 13, 781-792.

28. Nelson, A.R.; Fingleton, B.; Rothenberg, M.L.; Matrisian, L.M. Matrix metalloproteinases: Biologic activity and clinical implications. J. Clin. Oncol. 2000, 18, 1135-1149.

29. Rood, M.T.M.; Oikonomou, M.; Buckle, T.; Raspe, M.; Urano, Y.; Jalink, K.; Velders, A.H.; van Leeuwen, F.W.B. An activatable, polarity dependent, dual-luminescent imaging agent with a long luminescence lifetime. Chem. Commun. 2014, 50, 9733-9736.

30. Solomon, M.; Guo, K.; Sudlow, G.P.; Berezin, M.Y.; Edwards, W.B.; Achilefu, S.; Akers, W.J. Detection of enzyme activity in orthotopic murine breast cancer by fluorescence lifetime imaging using a fluorescence resonance energy transfer-based molecular probe. J. Biomed. Opt. 2011, 16, doi:10.1117/1.3594153.

31. Goergen, C.J.; Chen, H.H.; Bogdanov, A.; Sosnovik, D.E.; Kumar, A.T.N. In vivo fluorescence lifetime detection of an activatable probe in infarcted myocardium. J. Biomed. Opt. 2012, 17, doi:10.1117/1.JBO.17.5.056001.

32. Steunenberg, P.; Ruggi, A.; van den Berg, N.S.; Buckle, T.; Kuil, J.; van Leeuwen, F.W.B.; Velders, A.H. Phosphorescence imaging of living cells with amino acid-functionalized tris(2-phenylpyridine)iridium(iii) complexes. Inorg. Chem. 2012, 51, 2105-2114.

33. Lakowicz, J.R. Principles of Fluorescence Spectroscopy, 2nd ed.; Kluwer Academic: New York, NY, USA, 1999.

34. Ishii, Y.; Yoshida, T.; Funatsu, T.; Wazawa, T.; Yanagida, T. Fluorescence resonance energy transfer between single fluorophores attached to a coiled-coil protein in aqueous solution. Chem. Phys. 1999, 247, 163-173.

35. Rabinovich, A.; Medina, L.; Piura, B.; Segal, S.; Huleihel, M. Regulation of ovarian carcinoma skov-3 cell proliferation and secretion of mmps by autocrine il-6. Anticancer Res. 2007, 27, 267-272.

36. Whitney, M.; Savariar, E.N.; Friedman, B.; Levin, R.A.; Crisp, J.L.; Glasgow, H.L.; Lefkowitz, R.; Adams, S.R.; Steinbach, P.; Nashi, N.; et al. Ratiometric activatable cell-penetrating peptides provide rapid in vivo readout of thrombin activation. Angew. Chem. 2013, 52, 325-330. 
37. Savariar, E.N.; Felsen, C.N.; Nashi, N.; Jiang, T.; Ellies, L.G.; Steinbach, P.; Tsien, R.Y.; Nguyen, Q.T. Real-time in vivo molecular detection of primary tumors and metastases with ratiometric activatable cell-penetrating peptides. Cancer Res. 2013, 73, 855-864.

38. Lee, S.; Lee, J.; Hohng, S. Single-molecule three-color fret with both negligible spectral overlap and long observation time. PLOS ONE 2010, 5, e12270.

39. Rae, M.; Fedorov, A.; Berberan-Santos, M.N. Fluorescence quenching with exponential distance dependence: Application to the external heavy-atom effect. J. Chem. Phys. 2003, 119, 2223-2231.

40. Doose, S.; Neuweiler, H.; Sauer, M. Fluorescence quenching by photoinduced electron transfer: A reporter for conformational dynamics of macromolecules. Chemphyschem 2009, 10, 1389-1398.

41. Zadran, S.; Standley, S.; Wong, K.; Otiniano, E.; Amighi, A.; Baudry, M. Fluorescence resonance energy transfer (fret)-based biosensors: Visualizing cellular dynamics and bioenergetics. Appl. Microbiol. Biotechnol. 2012, 96, 895-902.

42. Van Leeuwen, F.W.B.; Hardwick, J.C.; van Erkel, A.R. Luminescence-based imaging approaches in the field of interventional (molecular) imaging. Radiology 2014, in press.

(C) 2015 by the authors; licensee MDPI, Basel, Switzerland. This article is an open access article distributed under the terms and conditions of the Creative Commons Attribution license (http://creativecommons.org/licenses/by/4.0/). 